\title{
Analysis of the management and control of the education cost in the private colleges
}

\author{
Kuixia Zhang ${ }^{a}$, Chengwu Zheng ${ }^{b}$ \\ Qingdao Huanghai College, Qingdao 266427, China \\ a77410834@qq.com, b2290410584@qq.com
}

\begin{abstract}
The guarantee of cost control and quality of education in private colleges must be balanced and solved. Compared with other colleges and universities, the cost management of private colleges play an important role, which is related to the long-term development of private colleges. Cost management in the management of private colleges has been a problem. This article make an analysis from the cost management present situation of private colleges, which mainly from senior management, teacher management and basic management three aspects. Finally it is concluded that private colleges cost control and management advice.
\end{abstract}

Keywords: cost management; education resource allocation; private colleges.

\section{Introduction}

Since 1982, the concept of private colleges has been put forward for more than 30 years. In the case of shortage of public education resources, private colleges meet the needs of the national higher education.But the cost management in the rapid development of private education has become a bottleneck which restricts the improvement of education quality and management level, and also affects the image of private education. The current level of private colleges uneven in quality in China..A class of private higher education institution education and management level are in the forefront. While education and management level of Class ii and class iii private higher education institution are lag, and the cost control do not accord with the nature of education with commercial properties.

\section{Current situation of cost management in private higher education institutions}

\subsection{The chairman control core resource allocation of school}

According to the study found that China is currently about 4/5 private higher education institutions is high level management model of principal responsibility system under the leadership of the board of directors the chairman who control the core resources to allocate.School board member is mainly composed of investors, and other experts and representatives' position is equivalent to middle managers, no real decision-making power.Although many other school board members in composition is very complete, also conform to the requirements of the law, but the chairman as the only investor or school accounted for the vast majority of shares, allocate the school.core resource .Chairman and other investors are not educational experts, and do not understand the basic laws of education mostly. According to the aim of the enterprise to do education, the pursuit of cost minimization, they fail to acknowledge and deeply understand the learning goals of higher institutions--Communication and knowledge innovation, training and development talents to serve the society.And the principal is an expert in education and school administrators, the pursuit of high quality, high level and has characteristic of running a school, to pursue the idea of education is the highest.Therefore, the conflict between the principal and the board of directors is essentially the conflict between owners and managers, and managers are ultimately subject to the resolution of the board of directors as a major resolution and conflict resolution.

\subsection{Teachers' working system is not scientific, lack of incentives}

The quality of teachers is the quality of education, and the gap of education is the difference between teachers. Having a high quality, stable and full - time teacher team make private higher 
education institutions characteristic, quality and connotation. At present, our country private colleges cannot get the horizontal funds, and the longitudinal funds are less and less. To support the school by fees make incentive shortage, at a low level of maintenance of the status.

(1) The workload of teachers in private higher education institutions have heavy workload, variety work, low degree professional work. All make teachers' job lack professional and achievement. Private colleges due to the school-running concept fuzzy, education teaching funds nervous, lack of school culture characteristic, Lack of scientific nature and the stability of working system, lack of attractive compensation system, so all these reasons lead to lack of teacher resources. Lack of teachers have a teacher take part in several courses at the same time generally in private colleges. According to the survey, the amount of teachers in private colleges undertake 18 or even 20 sections, and the course of the subject area is large or even different. This leads to the teacher's authority and professionalism is not high, the work intensity and pressure, but also lack of teachers should have a sense of achievement. In addition most of private college teachers are often a multitask, as a head teacher, teacher, and Careers Teacher, etc. at the same time such different work, which do not specialize in job burnout and low enthusiasm.

(2) The compensation system does not conform to the teacher's professional characteristics

The lack of scientific and effective design, organization and management of the teachers work in the private colleges lead to the lack of corresponding compensation management system, scientific and reasonable system. The mission of teaching and educating makes the teacher respect needs and self-realization needs to be dominant than other careers, but the premise is the basic need to meet. Private colleges emphasis on incentives that job satisfaction and a sense of achievement effects on teachers' thought and behavior too much under the premise of hygiene factors are not met. At present, many private college teachers pays are low and the structure are not the reason in our country. Teachers' salaries in about $40 \%$ for fixed compensation, unstable pay account for about $60 \%$ of the income. Although most have a pay-for-performance program run by the teachers' income, but the performance wage income ratio is low, about 15\%.Most schools still use piecework wage system concept, in a very low base salary level rely mainly on the increase of the workload to increase income. All kinds of security benefits of private teachers are not only lower than the level of similar units and the relative level of enterprises and institutions. Private colleges strictly control spending, reduce the cost of the use of teachers leads to teacher's low happiness, low work enthusiasm and passion, which leads to teachers' work lacks the sense of security of life, and the loss of teachers is serious.

(3) Do not take the teachers' continuing education, inadequate investment in scientific research. Private colleges teachers professional titles and education level is generally low, two head teachers' age structure, less intermediate. Professional title generally low, the pyramid. Private colleges does not pay attention to teachers' continuing education, the reward system is not perfect and small support. In addition, private colleges have less research investment and small scientific research projects, mainly to self-financing etc. lead to low gold content. In addition, the workload, Short board with professional title and educational background lead to the teachers' scientific research ability is generally not high, which does not conform to the nature of the work of college teachers.

\subsection{School conditions did not meet the basic requirements or lack of content, the efficiency of the operation is low and the effect is poor}

Attraction to teachers and students in a school includes the soft and hard environment. The soft environment includes: educational philosophy, school culture, learning atmosphere, he school system, sense of stability and security of occupation, sense of accomplishment and pleasure; the hard environment includes: campus environment, teaching facilities, accommodation, dining, living convenience etc. A well-known private colleges are mainly through the hard environment to attract new teachers and students, the construction of soft environment pay more attention to in recent years, but still lack of attention. And copycat phenomenon is quite serious, and lack of the characteristics. But there are more private schools cannot guarantee the basic material conditions of running a school. In order to save running cost, private colleges pursue extremely frugal guidelines on the operating 
conditions, even can't meet the basic requirement of modern education, so soft environment construction is impossible.

Basic conditions for private colleges in construction situation as follows: relative to the number of school teachers and students area is small and crowded. Many colleges have campus afforestation or poor campus environment, accommodation crude crowded, and imperfect student life supporting facilities (such as dining, shopping, travel, and other aspects). Teaching conditions: crowded classrooms and no modern teaching facilities, the use of multimedia resources for a few classes; laboratory and training room is not perfect, and obsolete equipment. The library has few books and has a short opening time.

\section{Suggestions for private colleges and universities cost control}

\subsection{Top management model change}

The chairman of the board delegated the education and teaching management authority to the president and other education experts, including teaching management, teacher management, experimental training, teaching facilities and equipment, scientific research, continuing education, etc. The chairman is responsible for the financial management, school enrollment and employment, school construction (including campus environment, student dormitory, cafeteria, library, gymnasium, teacher dormitory or apartment), outreach and publicity work, making strategic development plan with principals and experts.

Highlight the status of education expert, let good practical education workers to participate in school decision making. In the board of directors is no longer a substantial one chairman resolution, in the board of directors, Chairman of the board of directors and other shareholders accounted for $30 \%$ of the total voting rights; The principal and relevant experts board members account for $50 \%$ of the total voting rights, teachers and other education workers account for $20 \%$ of the voting rights. This model conforms to the characteristics of education, according to the education of law education, let the professionals do education.

\subsection{Reform teacher's work and management system to control cost scientifically}

Formulating a series of rules and regulations that conform to the characteristics of the school. Including post appointment and salary system, teacher system, teacher evaluation system, bonus and performance of the distribution system, the work quantity and quality attached to the salary and the performance level. The teachers' scientific research contributions, books, academic contributions should be bring into salary and reward system to highlight the different work of teachers. In addition, the private college teachers' salary and welfare level to the public universities line. Various social security system of the private colleges, such as medical insurance system, pension insurance system, housing accumulation fund system should improve to the level of public colleges.

Sound and perfect the system of professional title evaluation and the system of continuing education. The process of professional title in private college, the level of expert members, the assessment of professional titles should be in accordance with state regulations, with reference to public schools and the implementation of the actual situation of the school. Improve the credibility, authority and universality of professional title evaluation. Encourage teachers to continue to pursue a master's degree or doctorate, the school should be supported by funds and time. Teachers should be encouraged to actively participate in various academic and academic conferences, and provide with opportunities for excellent teachers to study abroad. Teachers are supported to improve the level of scientific research, books, papers and participation in social research. Enhance the professional level of teachers and scientific research level from a full range, on the basis of meet the basic needs of teachers and the fulfillment of teachers' higher level needs.

\subsection{Improve the school environment, change the mode of development, improve the quality of content}

Private colleges should attach importance to the construction of soft environment in the context of building a hard environment. They should start from the way of extension development into the 
connotation of development, and explore their school history, condition, resource characteristic orientation to improve the level of the school culture. The weakness of private colleges is the weakness of the system construction, imperfect system makes the low efficiency of private colleges. Therefore, Private colleges should pay more attention to system culture construction based on the material culture construction mature, improve the teaching system of the education. Through the institution construction to improve the efficiency of school operation, private colleges reduce the cost of running a school, establish the characteristics of school, establish their own brand, to determine the running segment of the market in the fierce competition in Education.

The mode of support the school by fees cannot meet the needs of high quality education. The private colleges should explore a variety of ways to raise funds actively, expand the mode for private colleges development, broaden the channels for more social donations. They should use flexibility and features to fight for social resources actively.

\section{Conclusion}

The development of private colleges cannot do without state funding and policy support, the state capital and other resources support can greatly reduce the cost of running. The purpose is that private colleges will be promoted to a higher level and more quickly on connotation of development.

\section{Acknowledgments}

This paper gets the funding of international cooperation training program for excellent teachers of universities in Shandong Province. This paper is the result of the research on the teaching reform of undergraduate universities in Shandong Province in 2015, which is based on the integration of school and enterprise: A case study of Qingdao Huanghai University (Item no: 2015M082).

\section{References}

[1] Yang Hui, Research on the cost management of human resources in Private Colleges. Enterprise research. (2014), N0.06, p.13-16.

[2] Zhu Na, The problems, causes and solutions of the construction of the teachers in the new private colleges. (Doctor, Huazhong Normal University, China2012).p.4-7.

[3] Qian jing, Xu Mingwei. The plight and Countermeasures of the connotation construction of Private Colleges. Journal of Huang He S\&T University. (2016), N0.06, P.40-41.

[4] Zheng Qianbao, Yan Chengying, Xule, Problems and suggestions on cost management in private colleges. New education era. (2015), N0.01, p.255.

[5] Liu Congpeng. Research on the Countermeasures of speeding up the development of modern vocational education in Tianjin. Tianjin Ecnomics. 2016, N0.08, p.29.

[6] Zhu Yonghen, Zhang Jianyi. Analysis of the path of management and management in private colleges. Education and Teaching Forum. (2015), N0. 08, p.17-18.

[7] Yang qing. The innovation of human resources management and development of private colleges in the Career Academy. Journal of Lvliang College of Education. (2016), N0.06, p.49-50.

[8] Jiang Wenwen, Huang shuai. Construction of index system for the sustainable development of private higher education. Literature education. (2016), N0.07, p.141.

[9] Li Zhilian. nnovation guarantee long-term mechanism to stabilize the contingent of teachers in Private Higher Vocational Colleges. Science Journal (late). (2016), N0.07, p.50.

[10]Chen Jinxiu. Research on the management system of Private Higher Vocational Education-Taking Shandong Province as an example. (Master, Shandong Normal University. China2014). p. 47-53. 